\title{
EXPERIMENTAL EVALUATION OF 3-DIMENSIONAL KINEMATIC BEHAVIOR OF THE CRUCIATE LIGAMENTS
}

Silvio Antonio Garbelotti Júnior ${ }^{1}$, Osvaldo Pelozo Júnior ${ }^{1}$, Rogério Pedreschi Caldana ${ }^{2}$, Amâncio Ramalho J' ${ }^{\mathrm{r}}$, Ricardo Luiz Smith ${ }^{1}$

Garbelotti Jr SA, Pelozo Jr O, Caldana RP, Ramalho Jr A, Smith RL. Experimental evaluation of 3-dimensional kinematic behavior of the cruciate ligaments. Clinics. 2007;62(5):619-26.

PURPOSE: The purpose of this study was to evaluate a low-cost and easily reproducible technique for biomechanical studies in cadavers. In this kind of study, the natural effect of loading of the joint and shear forces are not taken into account. The objective is to describe the plastic deformation of the ligaments into 3-dimensional space.

METHOD: For 18 intact human cadaver knees, the cruciate ligaments were divided into 3 fiber bundles, the tibial or femoral fixation points were marked, and 2 perpendicular different $\mathrm{x}$-ray exposures were performed, thus obtaining radiographs of spatial projections of the bundle in 3 anatomic planes (frontal, sagittal, and transversal). From the measurements made on the x-ray films, we obtained the average distance between the 2 fixation points of the cruciate ligaments on the tibia and the femur at 4 different flexion angles.

RESULTS: The distance between the fixation points of the medial and lateral fiber bundles of the cruciate ligaments did not change significantly during movement. There were, however, significant variations $(P<.05)$ in the distance between the fixation points of the posterior fiber bundles of the anterior cruciate ligament and the anterior fiber bundles of the posterior cruciate ligament.

CONCLUSIONS: This technique was efficient for demonstrating the plastic deformability of the cruciate ligaments. The results proceeding from this type of study can assist in the planning of physical rehabilitation programs.

KEY-WORDS: Anatomy. Biomechanics. Knee. Fiber bundles. Plastic deformability.

\section{INTRODUCTION}

In the general literature, one finds simplistic and limited descriptions of the function of the cruciate ligaments, explaining that the anterior cruciate ligament (ACL) restrains posterior displacement of femur during leg extension, and the posterior cruciate ligament (PCL) restrains anterior displacement of femur during leg flexion in a close kinetic chain. However, since Brantigan \& Voshell $^{1}$ described the cruciate ligaments as being formed by 2 func-

1. Federal University of São Paulo - Morphology, São Paulo, SP, Brazil 2. Federal University of São Paulo - Department Image Diagnostic, SP, Brazil Email: garbelotti@terra.com.br

Received for publication on May 30, 2007

Accepted for publication on July 07, 2007 tionally independent subdivisions, called fiber bundles (1 anterior and 1 posterior), several other researchers such as Girgis et $\mathrm{al}^{2}$ have directed their efforts to describing the functional behavior of these fiber bundles.

Because of the variation of the insertion points of the fiber bundles, the cruciate ligaments can stabilize the articulation simultaneously in several different directions during knee movement.

For Fuss ${ }^{3,4}$ and Mommersteeg et al, ${ }^{5}$ it is evident that the state of tension of a ligament being constant or variable depends on the distance between its bone insertions points, such as collagen fibers that only tension when the distance between insertion points increases. These researchers consider this to be the key point for a functional description of cruciate ligaments. The plasticity of both 
cruciate ligaments is sensitive to attachment site position, ${ }^{6}$ principally on the femur, and this factor emphasizes the importance of the anatomical and biomechanical precepts during cruciate ligament reconstruction procedures.

Several techniques for the biomechanical study of the cruciate ligament have been described. Some researchers have reconstructed the cruciate ligaments using literature based on theoretical computerized models. ${ }^{7,8}$ Others have evaluated the resistance of cruciate ligaments by means of variable linear displacement transducers. ${ }^{9}$ A universal force sensor placed in cadaver knees was used to describe the function of the ligaments or graft placement in various knee joint degrees of freedom. ${ }^{10-13}$

The purpose of this study was to evaluate a low-cost and easily reproducible technique for biomechanical study in cadaver subjects. In this kind of study, the natural effect of loading of the joint and shear forces is not taken into account. The objective is to describe the plastic deformation of the ligaments in 3-dimensional space. Using a technique involving $\mathrm{x}$-ray films, the present study evaluates the behavior of the fiber bundles of the ACL and the PCL in 4 different positions of articulation.

\section{MATERIALS AND METHODS}

In this study, 18 intact, human, adult, male, cadaver knees, free from degenerative diseases, with their surrounding soft tissues, were cut at the proximal third of the tibia and the distal third of the femur. Dissection was performed to preserve the lateral, medial, and posterior part of the joint capsule, menisci, collateral ligaments, patellar tendon, and cruciate ligaments. The external structures were folded back to obtain better intra-articular access. For better visualization of the structures, the femur was divided into 2 parts along the sagittal plane, and the sinovial ligament covering membrane was removed. Then, the femur was connected by previously arranged screws. The tibial insertion points were defined as having a triangular form, which through their vertices determined 3 fiber bundles for each ligament., Lateral, medial, and posterior fiber bundles were observed for the ACL; and lateral, medial, and anterior fiber bundles were observed for the PCL.

To identify the fiber bundles in the X-ray films, the tibia and femur insertion points were differentiated by means of metal pins of different lengths.

\section{Radiographic Examination}

This study included $x$-ray examination of the samples for evaluation of the tibia and femur insertion points of the cruciate ligaments. A Medicor Röntgen Emerix ${ }^{\circledR}$ UV-56 machine was used to produce the $\mathrm{x}$-ray films.

The knees were positioned in a holding device and fixed by means of a metal pin through the center of the device so as to maintain a $90^{\circ}$ angle with respect to the base, allowing free femur movement.

Starting the extension movement at $0^{\circ}$, measurements at $30^{\circ}, 60^{\circ}$, and $90^{\circ}$ were effected by means of an international standard goniometer.

For each flexing position, we obtained 2 perpendicular exposures (lateral and frontal) to account for the 3 projections of the fiber bundles at the frontal, sagittal, and transversal planes (Figures 1 and 3). A support with a perfect square basis, where the tibia was fixed in a central shaft, guaranteed the correct positioning of the knee opposite the $\mathrm{x}$-ray machine for perpendicular orthogonal images. To avoid discrepancies between images, the distance between the samples, film, and $\mathrm{x}$-ray source was kept constant.

\section{Analysis of the images}

We obtained $\mathrm{x}$-ray films of samples placed in a horizontal plane at $0,30^{\circ}, 60^{\circ}$, and $90^{\circ}$ flexion positions. For each of these positions, images of 2 perpendicular orthogonal incidences (anterior-posterior and latero-lateral) were obtained.

Initially, for all x-ray films, we drew a longitudinal anatomical axis of the tibia. Immediately and in continuation, for the x-ray films with anterior-posterior exposure, vertically to the longitudinal axis of the tibia, we drew a horizontal axis that would accumulate the values for $\mathrm{x}$ coordinate. Related to this axis we drew a second vertical axis representing the y coordinates. For the x-ray films with latero-lateral (profile) exposure perpendicular to the longitudinal axis of the tibia, we drew a horizontal axis that would accumulate the $\mathrm{z}$ coordinates. In relation to this axis, we drew a second vertical axis that would again represent the y coordinates (Figures 1 to 4 ).

Thus, on the $\mathrm{x}, \mathrm{y}$, and $\mathrm{z}$ axes, we could project all straight lines uniting the tibial-femoral fixation points (tibia-femur segments $=\mathrm{TF}$ ) representing the fiber bundles in the horizontal and vertical planes, respectively, perpendicular and parallel to longitudinal anatomical axis of the tibia (Figures 2 and 4). Then we measured the horizontal and vertical projections of the fiber bundles of both cruciate ligaments on 3 orthogonal axes, furnishing 6 coordinates for each fiber bundle for each angular situation. To define the coordinates and to avoid bias, we considered the average of 3 nonsequential measurements.

The length of the projections was obtained by the difference of the pairs between the measurements of the coordinates represented by the $\mathrm{x}, \mathrm{y}$, and $\mathrm{z}$ axes. Length $X$ was 


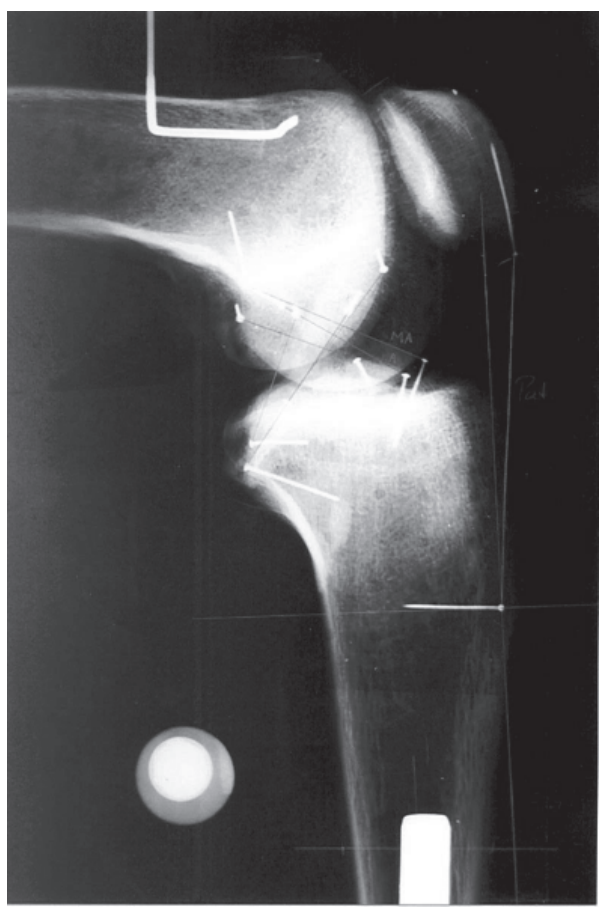

Figure 1 - Radiograph of a lateral view of the knee in $90^{\circ}$ flexion (specimen no. 16). Note the metallic pins on the femoral and tibial cruciate ligament attachment sites and metallic pin on the tibial protuberance used as a reference for the tibial anatomical axis.

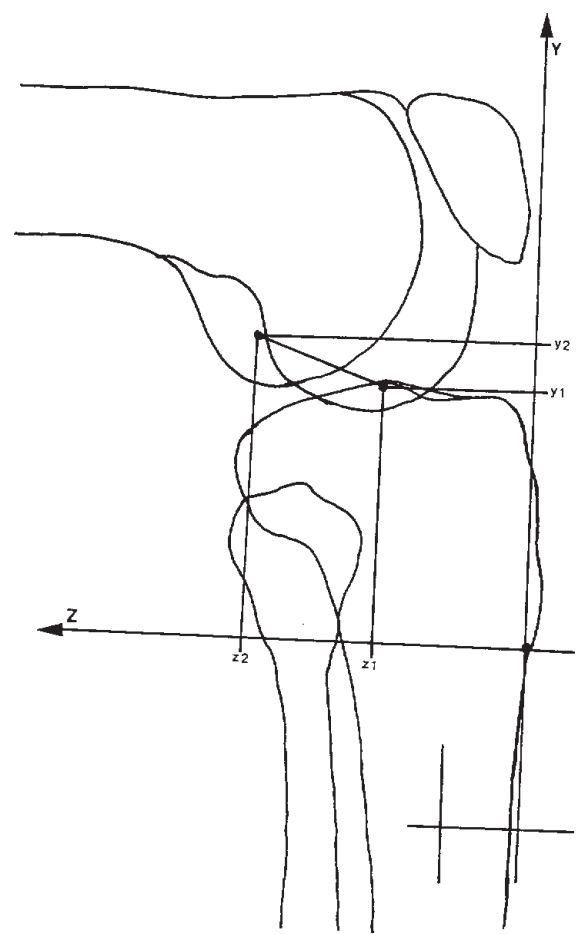

Figure 2 - Schematic drawing of Figure 1 showing the segment described as posterior bundle of anterior cruciate ligament and the projections on the $\mathrm{y}$ and $\mathrm{z}$ coordinates, drawn in relation to the tibial anatomic axis. The value of the segment for each bundle was found by subtracting coordinate values referring to femoral and tibial attachments, as follows: for the length in the $\mathrm{y}$-axis, $Y=\mathrm{y}_{2}-\mathrm{y}_{1}$, and for length in the $\mathrm{z}$-axis, $Z=\mathrm{z}_{2}-\mathrm{z}_{1}$.

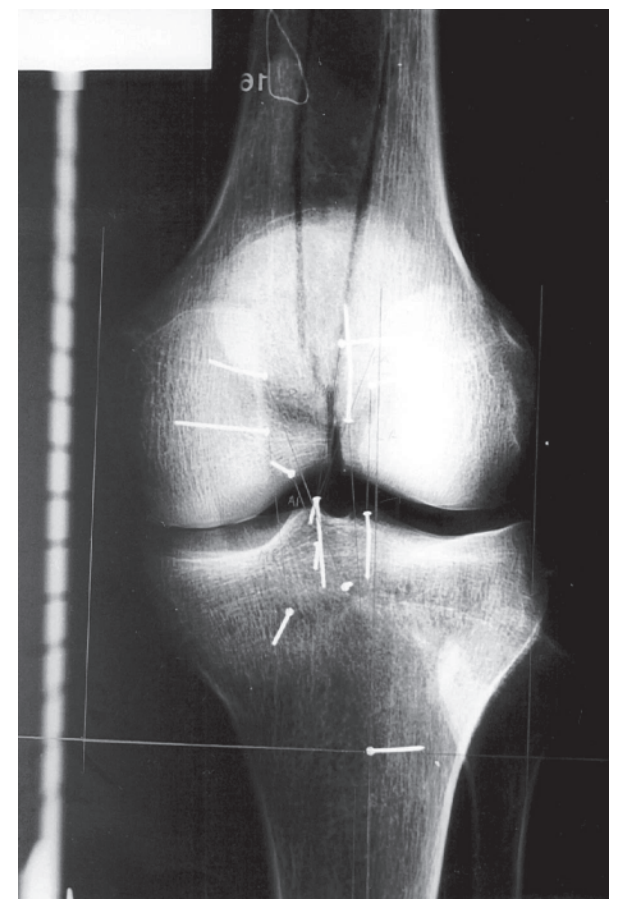

Figure 3 - Radiograph of an anterior-posterior view of the knee in extension $0^{\circ}$ (specimen no. 16), where the metallic pins of the femoral and tibial attachment points as well as the metallic pin on the tibial protuberance (anatomical axis) can be observed.

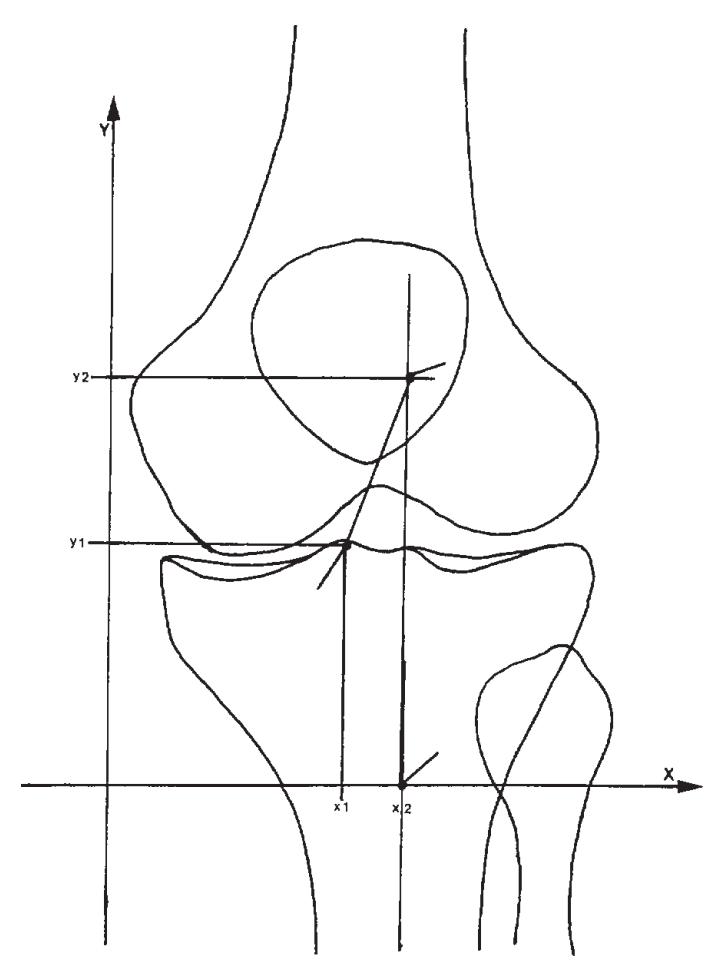

Figure 4 - Schematic drawing of Figure 3, showing the segment described as the posterior bundle of the anterior cruciate ligament and its projection on the $\mathrm{x}$ and $\mathrm{y}$ coordinates drawn in relation to the tibial anatomic axis. The value of the segment of each bundle was found by subtracting the coordinate values referring to femoral and tibial attachment, as follows: for the length in the $\mathrm{x}$-axis, $X=\mathrm{x}_{2}-\mathrm{x}_{1}$, and for length in the $\mathrm{y}$-axis, $Y=\mathrm{y}_{2}-\mathrm{y}_{1}$. 
Table 1 - Distribution of data obtained representing the average bundle length change in relation with flexion angles.

\begin{tabular}{llccccc}
\hline & Bundle & $0^{\circ}$ & $30^{\circ}$ & $60^{\circ}$ & $90^{\circ}$ & SD Range \\
\hline A & Medial & $36,06 \pm 4,83$ & $36,50 \pm 5,51$ & $37,51 \pm 5,64$ & $37,95 \pm 6,06$ & $37,00 \pm 0,88$ \\
C & Lateral & $30,90 \pm 6,16$ & $30,22 \pm 6,45$ & $30,53 \pm 5,62$ & $31,66 \pm 5,65$ & $30,83 \pm 0,62$ \\
L & Posterior* & $29,87 \pm 5,73$ & $27,51 \pm 6,06$ & $25,26 \pm 6,17$ & $23,78 \pm 5,83$ & $26,61 \pm 2,67$ \\
P & Medial & $30,44 \pm 7,20$ & $30,37 \pm 6,43$ & $32,15 \pm 7,14$ & $34,45 \pm 7,63$ & $31,85 \pm 1,92$ \\
C & Lateral & $36,83 \pm 6,53$ & $36,86 \pm 5,25$ & $37,79 \pm 5,34$ & $37,81 \pm 5,52$ & $37,32 \pm 0,55$ \\
L & Anterior** & $21,99 \pm 4,82$ & $25,42 \pm 5,59$ & $30,43 \pm 5,92$ & $33,80 \pm 5,50$ & $27,91 \pm 5,24$ \\
\hline
\end{tabular}

Data in average \pm standard derivation (SD); Exact Fisher test $p>0,05$ - Significant: $(*)$ Fo=3,61 and $(* *)$ Fo=16,49.

Length in milimeters; $\mathrm{ACL}=$ Anterior Cruciate Ligament; $\mathrm{PCL}=$ Posterior Cruciate Ligament.

the result of the difference between coordinates $\mathrm{x}_{2}-\mathrm{x}_{1}$; length $Y$ was the result of the difference between coordinates $\mathrm{y}_{2}-\mathrm{y}_{1}$, and length $Z$ was the difference between coordinates $\mathrm{z}_{2}-\mathrm{z}_{1}$.

Using this dimensional data in a trigonometric calculation applying the Pythagoras theorem, we determined the distance between fixation points of the ACL and PCL fiber bundles in 4 different positions.

We used Microsoft Excel ${ }^{\circledR} 7.0$ for the ordered and sequential calculation of the segment lengths (TF) according to the following equation:

$$
|\mathrm{TF}|=\sqrt{(X)^{2}+(Y)^{2}+(Z)^{2}}
$$

where, $X$ is the measure of the horizontal projection of the ligament fiber bundle, $Y$ is the measure of the vertical projection of the anterior-posterior and latero-lateral x-ray exposure, and $Z$ is the measure of the horizontal projection, also in the latero-lateral $\mathrm{x}$-ray exposure.

This data supplied the arithmetical average length of the tibia-femur segments (TF).

\section{Statistical Analysis}

The chi-square test was used to analyze the degree of independence between the variables. For comparison between the averages of 1 fiber bundle during the articulate excursion, with the purpose to analyze the significance of the variation during the progress of a movement, we used Fisher's exact test.

\section{RESULTS}

The main aspect of the analysis of the results was the changes of length of the cruciate ligaments through the variation of the actual length of each of the fiber bundle, emphasizing that the measurements listed are 3-dimensional.

The most evident results showed that the posterior fiber bundle of the ACL, the length of which varied around 26.61 $\pm 2.67 \mathrm{~mm}$, and the anterior fiber bundle of the PCL, which had an average length of $27.91 \pm 5.24 \mathrm{~mm}$, were the fiber bundles that underwent the largest length change, an average of $6.09 \mathrm{~mm}(P<.05)$ and $11.81 \mathrm{~mm}(P<.05)$, respectively. These changes were considered significant, the posterior fiber bundle of the ACL presented the biggest length change as a consequence of being the highest tensed at the $0^{\circ}$ position. In compensation, the anterior fiber bundle of the PCL presented its biggest length as a consequence of its highest tension at $90^{\circ}$ of flexion.

Also evident was that the medial and lateral fiber bundles of the anterior and PCLs practically maintain their length during the flexion movement. The dimensional changes were not statistically significant.

All results obtained regarding the averages of the lengths $(\mathrm{mm})$ of each fiber bundle forming the cruciate ligaments during flexion at $0,30^{\circ}, 60^{\circ}$ and $90^{\circ}$ are listed in Table 1 . The graphic representations of the variations of the length measurements in relation to the flexion angles are shown in Figures 5 and 6 for the anterior and posterior cruciate ligaments, respectively.
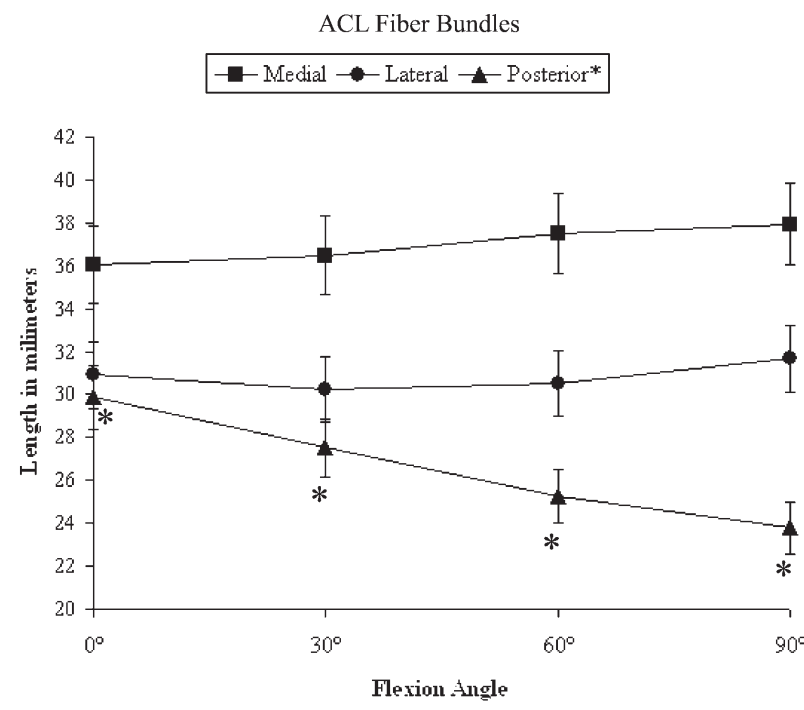

(*) Significant; $P>.05$

Figure 5 - Fiber bundle length changes of anterior cruciate ligament with flexion angle change. 


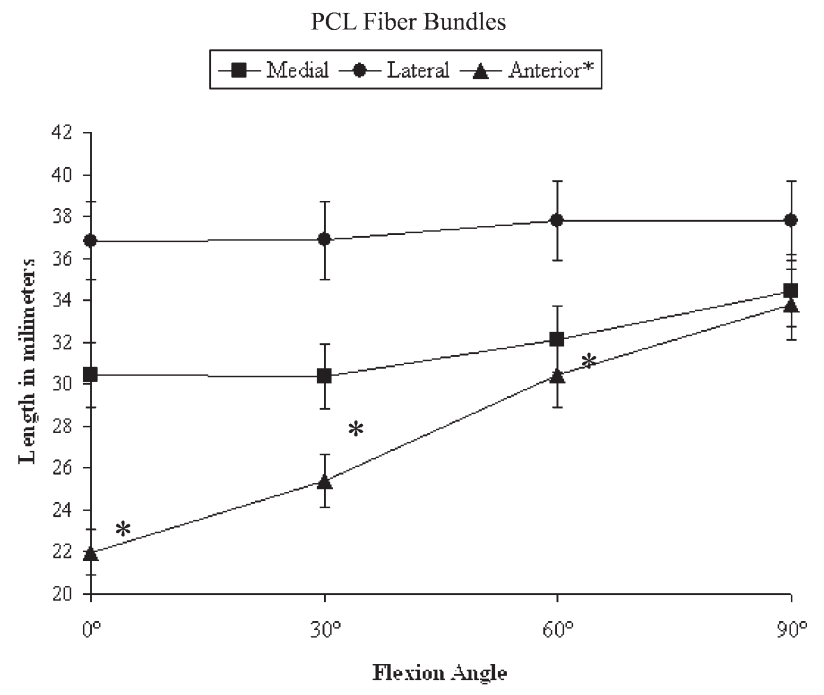

(*) Significant; $P>.05$.

Figure 6 - Fiber bundle length changes of the posterior cruciate ligament with flexion angle change.

\section{DISCUSSION}

We found incompatible data in the literature regarding the fiber bundles of the cruciate ligaments, mainly because of the different techniques used for the dissection and preparation of the anatomical samples. Amis \& Dawkins ${ }^{14}$ affirmed that the use of the instruments for dissection in the separation of the fiber bundles may exceed the limit of their original form. This fact may hamper the creation of a standard model for these fiber bundles. Observing this detail, we agree with Girgis et $\mathrm{al}^{2}$ who maintained that there is no microscopic or macroscopic division, defending a functional division of these fiber bundles.

Contrary to authors such as Horwitz, ${ }^{15}$ who divided the cruciate ligaments into 2 bundles of fibers, but in agreement with Norwood \& Cross, ${ }^{16}$ the present study confirms the cruciate ligament as possessing 3 bundles of fibers that intertwine among themselves during leg flexion.

\section{Anterior cruciate ligament}

\section{Medial and lateral bundles (guides)}

Penner et a $1^{12}$ described similar data to ours for the more anterior fiber bundle of the ACL, with a final increase of $1.0 \mathrm{~mm}$ in the length of the fiber bundle. Livesay et $\mathrm{al}^{10}$ observed that the anterior bundle "carried higher forces" than the posterior "at both $60^{\circ}$ and $90^{\circ}$," while Markolf et $\mathrm{al}^{17}$ and Sakane et $\mathrm{al}^{13}$ reported that this bundle was more active beyond $45^{\circ}$ and was less active near full extension $\left(0^{\circ}\right)$. The data of Inderster et al, ${ }^{18}$ however, showed a decrease of $0.7 \mathrm{~mm}$ and $4.7 \mathrm{~mm}$, respectively, in length of the medial and lateral fiber bundles. Although no detailed numerical data was furnished, Trent et $\mathrm{al}^{19}$ described the movement of the medial and lateral fiber bundles similar to our results. In agreement with this fact are Boisgard et $\mathrm{al},{ }^{20}$ Bradley et al, ${ }^{21}$ Sakane et al, ${ }^{13}$ and Li et al ${ }^{23}$ who also described an isometric pattern for these bundles. On analyzing these results, attention was called to the fact that these fiber bundles comprise a standard similar to the "guide bundle" described by Fuss, ${ }^{3,4}$ being determined by this researcher as "the most anterior bundle of the ACL" because, as described by the researcher, these bundles remain with their length practically unchanged, giving a clear demonstration that they are important articular stabilizers in all angular moments of the movement.

\section{Posterior fiber bundles}

Sapega et $\mathrm{al}^{9}$ presented variations very similar to ours, mentioning that for this fiber bundle, he found a decrease of $5.4 \mathrm{~mm}$ in the length when the movement went from extension to flexion. A large number of the studies that we analyzed presented a standard movement similar to ours, ie, constant and decreasing, ${ }^{13,22,23}$ although sometimes with small variations, such as in the study of Horwitz ${ }^{15}$ who reported a small initial increase $\left(0^{\circ}-30^{\circ}\right)$ followed by the relaxing of the fibers up to the $90^{\circ}$ flexion. As a counterpoint, other researchers, such as Penner et al, ${ }^{12}$ have presented results totally contrary to those presented in our study and indicate an average increase of $8.1 \mathrm{~mm}$ in the total length of the posterior fiber bundle of the ACL, which has been supported by researchers such as Crowninshield et $\mathrm{al}^{7}$ who also described a constant elongation of these fibers during flexion. These data suggest that this bundle is more active during knee extension.

\section{Posterior Cruciate Ligament}

\section{Lateral bundle}

Our results concur with those of Inderster et $\mathrm{al}^{24}$ and $\mathrm{Li}$ et $\mathrm{al}^{23}$ who reported that the distance between the tibial and femur insertion increased. Starting from extension and flexing the knee to $90^{\circ}$, the average length was increased by only $0.98 \mathrm{~mm}$. However, this bundle can be considered as being similar to the one Fuss ${ }^{3,4}$ described as a guide bundle because it is constantly tense in all degrees of flexion. On the other hand, contrary to our data, Grood et $\mathrm{al}^{26}$ reported a gradual standard slackening of the fibers.

\section{Medial bundle}

For the medial bundle of the PCL, Inderster et $\mathrm{al}^{24}$ found a gradual and constant increase in fiber bundle length, mainly in the first $60^{\circ}$, with a $2.7-\mathrm{mm}$ increase during the 
movement of $0^{\circ}$ to $30^{\circ}$, a $2.1-\mathrm{mm}$ increase from $30^{\circ}$ to $60^{\circ}$, and in the last stage of the movement $\left(60^{\circ}\right.$ to $\left.90^{\circ}\right)$ only a 0.7-mm increase in fiber length; in total, an increase between the points of insertion of the fiber bundles of $5.5 \mathrm{~mm}$ occurred. Researchers who agree with the standards indicated by our results for these fiber bundles are Crowninshield et $\mathrm{al}^{7}$ and Shelburne \& Pandy, ${ }^{27}$ although the latter reported a slight slackening of the fibers in the $30^{\circ}$ to- $60^{\circ}$ angular moment, and Fox et $\mathrm{al}^{28}$ and $\mathrm{Li}$ et $\mathrm{al}^{23}$ found a maximum tension of the bundle at $90^{\circ}$. On the other hand Kurosawa et $\mathrm{al}^{29,30}$ described a slackening of the fibers in the most posterior positions, while Beynnon et $\mathrm{al}^{22}$ reported a slackening of the fibers as a unit during knee flexion, and Amis et $\mathrm{al}^{31}$ reported that the posterolateral and posteromedial structures tighten as the knee extends. Harner et $\mathrm{al}^{32,33}$ indicated that this bundle plays an important role in joint stabilization after PCL reconstruction.

\section{Anterior bundle}

Regarding the anterior bundle of the PCL, Grood et $\mathrm{al}^{26}$ described it with a standard distance from the femur and tibia insertion points of its fibers, showing a gradual, constant elongation. Crowninshield et $\mathrm{al}^{7}$ and Makris et $\mathrm{al}^{25}$ found that the most anterior portion of the cruciate ligament does not undergo much length change, while Kurosawa et $\mathrm{al}^{30}$ found a slight slackening of the fibers at the end of flexion $\left(60^{\circ}\right.$ to $90^{\circ}$ ). Fox et $\mathrm{al}^{28}$ found the highest resistance at $60^{\circ}$, while Beynnon et $\mathrm{al}^{22}$ and $\mathrm{Li}$ et $\mathrm{al}^{23}$ found a tensioning of the ligament in its totality. Inderster et al, ${ }^{24}$ when studying this fiber bundle, found a length variation of $6.3 \mathrm{~mm}$ in total length $\left(0^{\circ}\right.$ to $90^{\circ}$ of flexion), divided into $2.7 \mathrm{~mm}$ from $0^{\circ}$ to $30^{\circ}$, $2.1 \mathrm{~mm}$ from $30^{\circ}$ to $60^{\circ}$, and $1.5 \mathrm{~mm}$ from $60^{\circ}$ to $90^{\circ}$. Our results were quite similar to those presented by these re- searchers, suggesting that this bundle is more active during the knee flexion, in accordance with the findings of Bach et $\mathrm{al}^{6}$ and Harner et al. ${ }^{32,33}$

Therefore, we concluded that the cruciate ligaments can be divided into 2 functionally different portions. The first could be considered the base of the triangles that represent the fixation areas of the ACL and the PCL, through their medial and lateral fiber bundles. These regions are located at the more distant points from the center of the articulation. Since they are do not undergo significant variations in their lengths, they can be considered the portions responsible for maintaining the functional stability of the articulation during the whole of the movement. The second, located at the vertices of the triangles, would be the location of the posterior ACL fiber bundle and the anterior PCL fiber bundle. These areas, adjacent to the intercondilar eminence and consequently next to the center of the articulation, were those in which the most pronounced and significant variation in distance between the femur and tibia during movement occurs. From this observation, one could infer that the fiber bundles fixed on these points would be related to the progressive stabilization of the articulation, fibers being tensed in the proportion that flexion or extension of the knee occurs, in an authentic fiber-demand system.

\section{CONCLUSIONS}

This technique is efficient in demonstrating the plastic deformations of the cruciate ligaments, because the isometric patterns of the bundles cannot be observed through holistic observations and are primarily influenced by spatial orientation.

\section{RESUMO}

Garbelotti Jr SA, Pelozo Jr O, Caldana RP, Ramalho Jr A, Smith RL. Avaliação experimental do comportamento cinemático tridimensional dos ligamentos cruzados. Clinics. 2007;62(5):619-26.

OBJETIVO: Este trabalho sugere uma técnica de baixo custo e de fácil reprodutibilidade para o estudo biomecânico em cadáveres. Neste tipo de estudo os efeitos das cargas naturais na articulação não são estudados. $\mathrm{O}$ objetivo é descrever a deformação plástica dos ligamentos no espaço tridimensional.

MÉTODO: 18 joelhos provenientes de cadáveres humanos tiveram seus ligamentos cruzados divididos em três fei- xes de fibras cada e suas respectivas fixações tibiais e femorais marcadas, quando foram submetidos a duas exposições radiográficas perpendiculares para podermos obter uma projeção dos ligamentos nos três planos anatômicos (frontal, sagital e transversal). Através das medidas feitas nas radiografias nós obtivemos a média da distância entre os pontos de fixação na tíbia e no fêmur em quatro diferentes graus de flexão.

RESULTADOS: Analisando os dados nós observamos que a distância entre os pontos de fixação dos feixes medial e lateral de ambos os ligamentos cruzados não alterou de forma significativa durante o movimento. Contudo, houve variação significativa $(\mathrm{p}>0.05)$ na distância entre os pontos de fixação do feixe posterior do ligamento cruzado anteri- 
or e do feixe anterior do ligamento cruzado posterior. CONCLUSÕES: A técnica foi eficiente ao demonstrar a deformação plástica dos ligamentos cruzados. Os resultados provenientes deste tipo de estudo podem auxiliar no planejamento de programas de reabilitação física.

UNITERMOS: Anatomia. Biomecânica. Joelho. Feixe de Fibras. Deformação Plástica.

\section{REFERENCES}

1. Brantigan OC, Voshell AF. Mechanics of ligaments and menisci of the knee joint. J Bone Joint Surg. 1941;23:44-66.

2. Girgis FG, Marshall JL, AL Monajen ARS. The cruciate ligaments of the knee joint. Clin Orthop Rel Res. 1975;106:216-31.

3. Fuss FK. Anatomy of the cruciate ligaments and their function in extension and flexion of the human knee joint. Am J Anat. 1989;184:165-76

4. Fuss FK. Optimal replacement of the cruciate ligaments from the functional-anatomical point of view. Acta Anat. 1991;140:260-8.

5. Mommersteeg TJA, Kooloos JGM, Blankevoort L, Kauer JMG, Huiskes $\mathrm{R}$, Roeling FQC. The fibre bundle anatomy of human cruciate ligaments. J Anat. 1995;187:461-71.

6. Bach BR, Daluga DJ, Mikosz R, Andriacchi TP, Seidl R. Force displacement characteristics of the posterior cruciate ligament. Am J Sports Med. 1992;20:67-72.

7. Crowninshield R, Pope MH, Johnson RJ. An analytical model of the knee. J Biomech. 1976;9:397-405.

8. Veselko M, Godler I. Biomechanical study of a computer simulated reconstruction of the anterior cruciate ligament (ACL). Comp Biol Med. 2000;30:299-309.

9. Sapega AA, Moyer RA, Schneck C, Komalahiranya N. Testing for isometry during reconstruction of the anterior cruciate ligament: anatomical and biomechanical considerations. J Bone Joint Surg. 1990;72A:259-67.

10. Livesay GA, Rudy TW, Woo SL, Runco TJ, Sakane M, Li G, Fu FH Evaluation of the effect of joint constraints on the in situ force distribution in the anterior cruciate ligament. J Orthop Res. 1997;15:27884.

11. Mae T, Shino K, Miyama T, Shinjo H, Ochi T, Yoshikawa H, Fujie H. Single versus two-femoral socket anterior cruciate ligament reconstruction technique: Biomechanical analysis using a robotic simulator. Arthroscopy. 2001;17:708-16

12. Penner DA, Daniel DM, Wood P, Mishra D. An in vitro study of anterior cruciate ligament graft placement and isometry. Am J Sports Med. $1988 ; 16: 238-43$

13. Sakane M, Fox RJ, Woo SL, Livesay GA, Li G, Fu FH. In situ forces in the anterior cruciate ligament and its bundle in response to anterior tibial loads. J Orthop Res. 1997;15:285-93.

14. Amis AA, Dawkins GPC. 1991. Functional anatomy of the anterior cruciate ligament: fibre bundle actions related to ligament replacements and injuries. J Bone Joint Surg. 1991;73B:260-7.

15. Horwitz MT. An investigation of the surgical anatomy of the ligaments of the knee joint. Surg Gynec Obstet. 1938;67:287-92.
16. Norwood LA, Cross MJ. Anterior cruciate ligament: functional anatomy of its bundle in rotatory instabilities. Am J Sports Med. 1979;7:23-6.

17. Markolf KL, Willems MJ, Jackson SR, Finerman GA. In situ calibration of miniature sensors implanted into the anterior cruciate ligament part I: strain measurements. J Orthop Res. 1998;16:455-63.

18. Inderster A, Benedetto KP, Künzel KH, Gaber O. Fibers orientation of anterior cruciate ligament: an experimental morphological and functional study, part I. Clin Anat. 1993;6:26-32.

19. Trent PS, Walker PS, Wolf B. 1976. Ligament length patterns, strength, and rotational axes of the knee joint. Clin Orthop Rel Res. 1976;117:26370 .

20. Boisgard S, Levai JP, Geiger B, Saidane K, Landjerit B. Study of the variations in length of the anterior cruciate ligament during flexion of the knee: use of a 3D model reconstructed from MRI sections. Surg Radiol Anat. 1999;21:313-7.

21. Bradley J, Fitzpatrick D, Daniel D, Shercliff T, O'Connor J. Orientation of the cruciate ligament in the sagittal plane: a method of predicting its length-change with flexion. J Bone Joint Surg. 1988;70B:94-9.

22. Beynnon B, Yu J, Huston D, Fleming B, Johnson R, Haugh L, et al. A sagittal plane model of the knee and cruciate ligaments with application of a sensitivity analysis. J Biomec Eng. 1996;118:227-39.

23. Li G, DeFrate LE, Sun H, Gill TJ. In vivo elongation of the anterior cruciate ligament and posterior cruciate ligament during knee flexion. Am J Sports Med. 2004;32:1415-20.

24. Inderster A, Benedetto KP, Künzel KH, Gaber O, Balyk RA. Fibers orientation of posterior cruciate ligament: an experimental morphological and functional study, part II. Clin Anat. 1995;8:315-22.

25. Makris CA, Georgoulis AD, Papageorgiou CD, Moebius UG, Soucacos PN. Posterior cruciate ligament architecture: evaluation under microsurgical dissection. Arthroscopy. 2000;16:627-32.

26. Grood ES, Hefzy MS, Lindenfield, TN. Factors affecting the region of most isometric femoral attachments. Part I: The posterior cruciate ligament Am J Sports Med. 1989;17:197-207.

27. Shelburne KB, Pandy MG. A musculoskeletal model of the knee for evaluating ligament forces during isometric contractions. J Biomech. 1997;30:163-76.

28. Fox RJ, Harner CD, Sakane M, Carlin GJ, Woo SLY. Determination of the in situ forces in the human posterior cruciate ligament using robotic technology: a cadaver study. Am J Sports Med. 1998;26:395-401.

29. Kurosawa H, Yasuda K, Yamakoshi KI, Kamiya A, Kaneda K. An experimental evaluation of isometric placement for extraarticular reconstructions of the anterior cruciate ligament. Am J Sports Med. $1991 ; 19: 384-8$ 
30. Kurosawa H, Yamakoshi KI, Yasuda K, Sasaki T. Simultaneous measurement of changes in length of the cruciate ligaments during knee motion. Clin Orthop Rel Res. 1991;265:233-40.

31. Amis AA; Bull AM; Gupte CM; Hijazi I; Race A; Robinson JR. Biomechanics of the PCL and related structures: posterolateral, posteromedial and meniscofemoral ligaments. Knee Surg Sports Traumatol Arthrosc. 2003;11:271-81.
32. Harner CD, Janaushek MA, Kanamori A, Yagi M, Vogrin TM, Woo SLY. Biomechanical analysis of a double-bundle posterior cruciate ligament reconstruction. Am J Sports Med. 2000;28:144-51.

33. Harner CD, Vogrin TM, Woo SLY. Anatomical and biomechanical considerations of the PCL. J Sport Rehab. 1999;8:260-78. 